\title{
Free-Wilson in the 21st Century-evolution of a versatile toolkit for SAR analysis
}

\author{
Brad Sherborne \\ From 6th German Conference on Chemoinformatics, GCC 2010 \\ Goslar, Germany. 7-9 November 2010
}

When drug discovery projects are transferred, then rapidly assessing the available SAR in both overview and in numerical detail is a prerequisite for effective computational chemistry input. Following multiple company acquisitions, regular requirements for the approach has led to an effective and fast platform for Free-Wilson [1] based SAR review: in fact the utility is sufficient that it can for a useful reporting or project browsing tool for the busy modeller. Figure 1

In this talk it is shown how a carefully crafted PDF report can be combined with "on the fly" Matched Molecular Pair [2] and other drill downs to provide a versatile platform for SAR exploration and presentation that is appealing and to medicinal chemists.

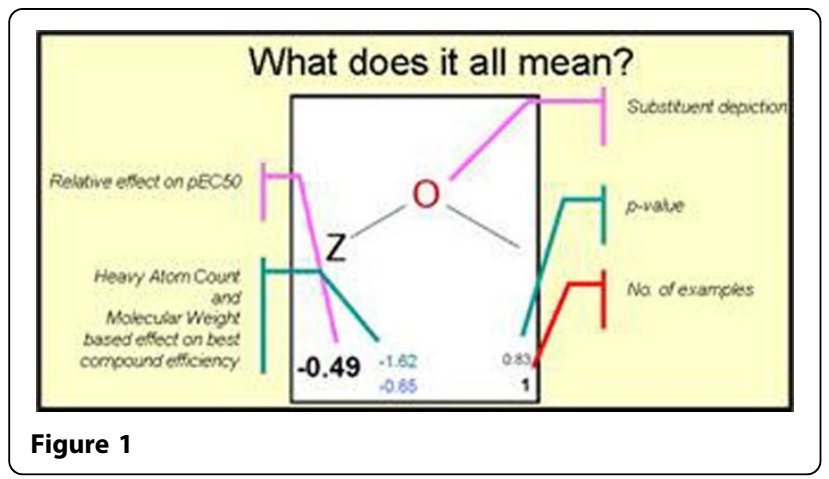

Published: 19 April 2011

\section{References}

1. Free SM Jr, Wilson JW: A Mathematical Contribution to Structure-Activity Studies. J Med Chem 1964, 7:395-399.

Correspondence: Brad.Sherborne@Merck.com

MSD, Newhouse, Scotland, ML5 1SH, UK
2. Leach AG, Jones HD, Cosgrove DA, Kenny PW, Ruston L, MacFaul P, Wood JM, Colclough N, Law B: Matched molecular pairs as a guide in the optimization of pharmaceutical properties; a study of aqueous solubility, plasma protein binding and oral exposure. J Med Chem 2006, 49:6672-6682.

doi:10.1186/1758-2946-3-S1-P6

Cite this article as: Sherborne: Free-Wilson in the 21st Centuryevolution of a versatile toolkit for SAR analysis. Journal of

Cheminformatics 2011 3(Suppl 1):P6.
Publish with ChemistryCentral and every scientist can read your work free of charge

"Open access provides opportunities to our colleagues in other parts of the globe, by allowing anyone to view the content free of charge."

W. Jeffery Hurst, The Hershey Company.

- available free of charge to the entire scientific community

- peer reviewed and published immediately upon acceptance

- cited in PubMed and archived on PubMed Central

- yours - you keep the copyright

Submit your manuscript here:

http://www.chemistrycentral.com/manuscript/

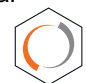

ChemistryCentral 